\title{
UNIVERSITYOF BIRMINGHAM

\section{The sociality of the wage : money rhythms, wealth circulation, and the problem with cash on the Zimbabwean-South African border}

\author{
Bolt, Maxim
}

DOI:

10.1111/jrai.2014.20.issue-1

License:

Creative Commons: Attribution (CC BY)

\section{Document Version}

Publisher's PDF, also known as Version of record

Citation for published version (Harvard):

Bolt, M 2014, 'The sociality of the wage : money rhythms, wealth circulation, and the problem with cash on the Zimbabwean-South African border', Journal of the Royal Anthropological Institute, vol. 20, no. 1, pp. 113-130. https://doi.org/10.1111/jrai.2014.20.issue-1

Link to publication on Research at Birmingham portal

Publisher Rights Statement:

Eligibility for repository : checked 03/04/2014

\section{General rights}

Unless a licence is specified above, all rights (including copyright and moral rights) in this document are retained by the authors and/or the copyright holders. The express permission of the copyright holder must be obtained for any use of this material other than for purposes permitted by law.

-Users may freely distribute the URL that is used to identify this publication.

- Users may download and/or print one copy of the publication from the University of Birmingham research portal for the purpose of private study or non-commercial research.

- User may use extracts from the document in line with the concept of 'fair dealing' under the Copyright, Designs and Patents Act 1988 (?)

- Users may not further distribute the material nor use it for the purposes of commercial gain.

Where a licence is displayed above, please note the terms and conditions of the licence govern your use of this document.

When citing, please reference the published version.

Take down policy

While the University of Birmingham exercises care and attention in making items available there are rare occasions when an item has been uploaded in error or has been deemed to be commercially or otherwise sensitive.

If you believe that this is the case for this document, please contact UBIRA@lists.bham.ac.uk providing details and we will remove access to the work immediately and investigate. 


\title{
The sociality of the wage: money rhythms, wealth circulation, and the problem with cash on the Zimbabwean- South African border
}

\author{
Maxim Bolt University of Birmingham
}

\begin{abstract}
While wage labour and money have received much anthropological attention, the same cannot be said of wages themselves - actual banknotes and coins distributed in workforces. This article traces wages' social productivity among farm workers on the Zimbabwean-South African border. In this migrant-labour setting, money's form matters. Because currency objects are physically the same, it is difficult for workers to store them in an insecure environment, leading them to turn to one another. As they manage their earnings, workers attempt to establish themselves as social persons while maintaining future options in uncertain circumstances. Workforce ties both shape and are constituted by flows of cash and the rhythms and circuits of the wage. Seen in terms of form, wages are highly personal - the very stuff of sociality.
\end{abstract}

\section{Payday: delay and dissatisfaction}

On the banks of the Limpopo River, a workforce grew increasingly impatient. Grootplaas, a 900-hectare South African citrus farm, had completed the 2007 harvest on Friday, but payday was delayed. By Sunday, the food budgets of the 450 Zimbabwean seasonal labourers began to run out. The 140 permanent workers still had some money, but lending to their harvest-time counterparts was risky. Driven to migration by Zimbabwe's economic and political crisis, many of the latter were strangers in - or only partial, precarious members of - the farm's resident population. Most would leave soon. They looked forward to receiving their remuneration, celebrating, and then heading south. Cities such as Johannesburg, they hoped, would offer further, perhaps better, employment. Now, however, an increasing number sat in groups in the labour compound, muttering complaints of hunger.

It was not only seasonal workers who were upset. At the end of each month, South African traders come up to the border farms from Musina, the border town 60 kilometres away, and from the former homeland of Venda beyond. Capitalizing on the huge influx of cash in the black workforces, they set up markets in the labour compounds. Moving between the border farms, they make as much as R12,0oo per month, ${ }^{1}$ beginning their sales early on the Friday afternoon when the first wages are distributed. This permits use, distribution and reproduction in any medium, provided the original work is properly cited. 
weekend, however, those at Grootplaas simply waited as rumour after rumour of imminent pay passed through the compound: the money would come by the end of Friday; by midday on Saturday; by Monday. In the meantime, many sat and slept in the same spots outdoors, holding onto their prime locations within the designated market space. As they faced the harsh late winter weather, the food they had brought for sustenance slowly ran out.

This dearth of cash made for a sharp contrast with the usual exuberance of payday weekend, and especially the end of the entire harvest. The purchase of clothes, groceries, and cosmetics from the market traders is followed by revelry. Despite the farm's remoteness, entrepreneurial senior workers schedule major music events. For performers, as for market traders, the border farms represent large, employed populations, in a region with high unemployment. And, for both, opportunities follow the monthly rhythm of life on the farms, built around the wage.

On this occasion, the event was a mere shadow of usual payday celebrations. Two major local pop stars failed to draw crowds. The Rio entry to the arena ${ }^{2}-$ demarcated from the football ground by a plastic sheet and wooden poles - was simply unaffordable for most seasonal labourers. Some listened under the trees outside. Few who did enter bought beer, ruining the usual atmosphere. Like the plans of the market traders and of the workers themselves, those of the concert organizers were thwarted by a delay to the farm's usual money rhythm.

Finally, at midday on Monday, an administrator cycled through the compound. The money had been sent from Musina, he announced, and was now being put into packets. By mid-afternoon, workers waited outside the perimeter fence of the farm workshop, as wages were finally distributed. Residents of the compound who had sold loose cigarettes, mbanje (marijuana), beer, and groceries on credit during the harvest now identified their customers. Consulting their brown-paper account books, they rushed to secure repayment before the seasonal workforce began to leave the farm. That evening, the visiting market traders were well compensated for their wait. Business boomed, as departing seasonal employees bought everything from cooking oil, soap, and skin cream, to clothes, shoes, music cassettes, and chips for snacking on while shopping - and Filipino suitcases (huge, tartan, woven-nylon bags) to transport their copious purchases and their other possessions.

Month-end is a major event, the subject of excited speculation. Will the manager of the seasonal-worker football team (a supervisor in the black workforce) provide meat for a braai (barbecue), to celebrate a successful tournament? Will the black manager of the nearby game farm - a friend of the foreman - slaughter one of his goats? Will there be music? Such anticipation may even result in workers travelling up and down the border between farms, trying to find events that never materialize, or never existed in the first place.

The exuberance of payday cannot be understood without appreciating the austerity of the period immediately preceding it. The social life of the border farms is profoundly shaped by rhythms of money circulation. Grootplaas is a place to which people come, from Zimbabwe, specifically to earn South African rand. Meanwhile, many residents survive the month on credit - in other words, by mobilizing their relationships as a means to access cash. Becoming known in this migrant workforce is marked by one's ability to borrow. But by the end of the pay cycle, the avenues open even to the best connected have been largely exhausted. Consumption of all but bare necessities is at an ebb. The compound is quiet and its residents turn in early. After all, in a place where 
shebeens (informal beersellers) are residents' adapted bedrooms, sitting at one without a beer is just loitering. The excitement that follows this lull is one reason why the farms are so lucrative at month-end for those willing to make the journey along the winding, uneven road that tracks the border fence.

At the end of the 2007 harvest, the delayed payday had far-reaching implications for many people, all of whom had finely calibrated their decisions and actions according to the precise timing of remuneration. For workers at Grootplaas, these decisions are not simply a matter of individual strategizing. The wage produces spatial circuits and temporal rhythms that profoundly shape life at the farm.

Matters are more complex still. As I will argue below, these circuits and rhythms are themselves mediated by - and produced through - a web of relationships in the workforce in which money is central: between white employers and black employees, among black workers, and between workers and businesspeople. Such relationships enable workers to safeguard, spend, and save cash amidst the everyday insecurity of a migrant-labour setting. In the process, they both reflect and reinforce hierarchy, offering a means of incorporation into the relative stability of workforce arrangements. Moreover, like money itself, the farm offers open-ended potential. How to balance life on the farm against plans elsewhere, which relationships to mobilize, and for how long are all open questions when recruits arrive at Grootplaas.

Wages are most visible, their importance most clearly dramatized, around payday. But the networks of sociality produced around the wage are implicated in the farm's entire monthly rhythm. And, while wages mediate intimacy, relationships take on some of money's flexibility. It is through money itself, therefore, that sociality at Grootplaas is constituted.

\section{The sociality of the wage}

This article explores how wages produce personal, as well as impersonal, relationships. In concentrated labour forces, the cash received from employers is absolutely central to the establishment of ties among workers. This is not simply a matter of money's social power in the act of consumption, communal or conspicuous. Workers' pay is itself socially productive. Wages shape everyday life's relationships, rhythms, and spatial dimensions.

The actual flow of wages through workforces often eludes anthropological attention. In southern Africa, to be sure, a vast literature has placed waged workplaces (see below) and migrant remittances (e.g. Murray 1981) at centre-stage. Yet what remains out of view are the particular relationships through which monetary objects - banknotes and coins - circulate in labour settings, constituting particular rhythms and places (Gilbert 2005; Maurer 2006: 21).

This means taking a broad view of how money changes hands: not merely transactions, but a wider range of transfers through which circuits and social possibilities are produced (Ferguson 1992; Guyer 2004; Shipton 2007). Wages are distributed (something logistically more complex than the exchange of currency for labour); they are entrusted, borrowed, and lent; and they are remitted. What I propose is not simply a focus on the wage relation itself, or on the moment of payment. This article traces outwards from remuneration. The distribution, storage, circuits, and rhythm of pay illuminate the complexities of money and sociality in a workforce.

To appreciate why wages' social productivity represents something of a lacuna in anthropology, it helps to recognize their social-theoretical baggage. To simplify matters, 
they lie at the intersection of two powerful narratives of modernity: that of wage labour, and that of money. Each, in turn, has focused anthropological approaches on particular questions, which overlook the everyday sociality of wages themselves.

Wage labour, as a way to organize production, has classically been associated with rupture. In Marx's somewhat ironic terms, workers are 'freed' from social and material obstacles - existing hierarchies and access to resources - to seek new employment, or reject wage work altogether and starve (see Elster 1985: 211). Though equipped with a different lens, Polanyi (2001 [1944]) similarly describes the atomization of workers' lives, and the disembedding of their labour from social relations as it is commoditized. ${ }^{3}$ This story about disembeddedness as a precondition for the creation of workforces also becomes one about the consequences of wage labour. The wage comes to stand for alienation, and the reduction of relationships and dependencies to contracts. In the critique of this broad narrative, labour processes, far from representing thoroughgoing alienation, are revealed to rely on webs of personal ties: personal, non-contractual obligations among workers (see, e.g., Burawoy 1979). Crucial here is the 'social embeddedness of capitalist forms of livelihood' (Mollona 2009: xvi). Thus the view from wage labour foregrounds the complex informal arrangements developed within workforces. But wages themselves generally appear extraneous to this cohesion, relevant only as systemic backdrop.

The story of wage labour is mirrored in the grand narrative of money, building on Marx and Simmel. As Bloch and Parry summarize, 'Anonymous and impersonal, money measures everything by the same yardstick and thereby - it is reasoned - reduces differences of quality to those of mere quantity' (1989: 6). Bohannan (1959) famously recounted how the Tiv's hierarchically ordered, qualitatively different spheres of exchange were corroded by 'general-purpose' colonial money. The idea that everything becomes priced, saleable, and alienable has been powerful. In a comprehensive review article, Maurer asks: "[W]hy is the anthropology of money still so often a retelling of the "great transformation"..., a compendium of exotica coupled with a morality tale about the world that "we" have lost?' (2006: 17). Nevertheless, this narrative, too, has been problematized. Money is far from simply the bearer of impersonal economic value. The ways it is 'represented' may be the result of particular cultural worldviews (Bloch \& Parry 1989). Or it may express people's subjectivities, their culturally specific assertions of agency (Walsh 2003). An important strand in the scholarship on money, then, foregrounds complex cultural meanings. This particularism can itself engender new universalism. From a culturalist perspective, money-as-wages can become the very symbol of the capitalist system (Comaroff \& Comaroff 1990; Taussig 1977). ${ }^{4}$

At first glance, Grootplaas appears to corroborate the old teleologies. Crisis in Zimbabwe has produced extreme rupture, causing countless people to travel - alone or in small groups - to places away from home to work for wages. There is constant movement through the farms as Zimbabweans cross the Limpopo River, climb through the fence, and work their way southwards into South Africa. When the farm is recruiting for the harvest, many stay as pickers or packshed workers. And while some work the full five-month period, others move on quickly, deterred by the conditions or lured by hopes of better employment elsewhere. On the farm, seasonal workers' insecure existence, bare accommodation, and merely provisional associations with one another turn them into conveniently malleable units of labour. Money seems equally austere. Discussion about mari (Shona: money) and mawages (wages) - beyond complaining about not having any, or about low pay - is muted. 
This first impression could be interrogated by elucidating wages' symbolic meaning at Grootplaas. Zimbabweans during the crisis spoke with embarrassment about the hyperinflating Zimbabwean dollar at home, a key reason for their leaving. Proliferating zeros on banknotes stood for disaster, and for the failures of Zimbabwe's Reserve Bank and its governor at the time, Gideon Gono. Wages in rand had their own associations. One Rastafarian picker referred to his employment as 'earning dollar', invoking the American currency of globalized popular culture. But the question remains: what do wages actually do in a workforce?

The work of Zelizer (1989), an economic sociologist, is suggestive, examining the particular social relations through which money works, and which money in turn shapes. In her case, this means challenging money's fungibility, its interchangeability. Even in the supposed monetary homogeneity of early twentieth-century America, people ascribed distinct meanings to different (figurative) pots of money, depending on purpose, origin, and access. Tracing wages ethnographically means understanding the place of money in the full range of social relations - from intimate to impersonal - as Zelizer suggests. Anthropologists of monetary circuits make similar points, focusing on forms of entrustment (Shipton 2007) and the remittances of migrant labourers (Ferguson 1992). Such an approach is imperative for understanding the lived experiences of wage-workforces.

However, unlike Zelizer's case, at Grootplaas it is precisely money's generic fungibility that shapes what people do with their pay. In this migrant-labour setting, the consequences of money's form require analysis. Because currency objects are physically the same, it is difficult for workers to store them in an insecure environment, leading them to turn to one another. Seen in terms of form, wages are highly personal - the very stuff of sociality.

On the Zimbabwean-South African border, workforces represent hubs of community in a transient setting, places where workplace hierarchies structure life more generally (see Bolt 2012; 2013). A core group of settled permanent employees - around 140 at Grootplaas - are connected to one another by ties of kinship, friendship, sexual relationships, and origin (many hail from villages just across the border). As on farms and mines elsewhere in southern Africa (see, e.g., Donham 2011; Gordon 1977; McNamara 1985; Moodie with Ndatshe 1994; Rutherford 2001), workers live in a designated, barrack-like labour compound in a racially divided landscape. This becomes a provisional home, shaped by relationships that spill over from work. Even as white farmers reject established ideals of paternalist responsibility (see Du Toit 1993), senior black workers reinforce personalized, vertical dependence, in what I call mediated paternalism (Bolt 2013). Such arrangements mitigate the border's uncertainty and transience.

Seasonal workers' incorporation resembles the 'declarations of dependence', the voluntary submission to powerful protectors, that Ferguson (2013) argues have long characterized southern African hierarchies. ${ }^{5}$ It is by appreciating workforce hierarchies that we understand the sociality of wages. Yet wages themselves profoundly affect the relations into which people enter. Money does not simply reflect existing hierarchies and dependencies; it establishes them. The need to store earnings is an important reason why new recruits seek the protection of senior figures, and money then becomes a channel for building vertical ties. Monetary rhythms are the rhythms of life at the farm. Everyone lives by the monthly cycle, with many borrowing money to even out the fluctuation. But marginal figures must repay loans more quickly than established 
residents. For seasonal workers, incorporation is quick, but partial and precarious, and relationships are often transient. Like money itself, the farm is a place of open-ended possibilities. Along with the flow of earnings, connections are mobilized, broken off, or withheld. While recruits' ultimate goals may remain undecided, their efforts to spend and save, and their efforts to become embedded at the farm - at least for a while - are woven together.

Following wages in the Grootplaas workforce means turning from the meaning of money to money's place in relations between people. ${ }^{6}$ In Maurer's $(2005 ; 2006)$ terms, I focus on the 'pragmatics' of money. Meanwhile, I put an emphasis on money back into the ethnographic study of labour. But this does not mean ignoring money's materiality. Quite the contrary: a focus on money in workforce arrangements responds to Gilbert's (2005) call to understand currency objects as they circulate in social networks. This, in turn, reveals how monetary circulation produces not only relationships, but also temporal rhythms and social spaces.

Doing this requires seeing the wage in broader terms than an economic moment, defined by legal contract. The article began with payday as an event within a social cycle. In what follows, I trace money before this moment, as white farmer-landowners bring it to the farms. A wage-centred view reveals farmers to be just as bound into this social world of monetary arrangements - far beyond the apparent neatness of the legal contract - as workers are. The article then examines how money is distributed and used in the workforce. What this shows is that, for Grootplaas workers, wages are at the heart of sociality. In this border setting, characterized by transience and a conspicuously absent police force, cash is a burden. Relationships of debt - potential cash - often form the basis of the monetary economy, and these both reflect and perpetuate existing social inequalities. Employers act as bankers for senior workers, and settled senior workers do the same for their seasonal counterparts. As everyone tries to remove his or her cash from a situation of everyday insecurity, money's use depends on highly personalized, hierarchical relationships. Successful workers skilfully mobilize expertise about farm arrangements simultaneously to secure money and to establish their social positions, even their personhood (see Guyer 2004: 131, 148). Workforce relationships both shape and are constituted by flows of cash. In turn, they illuminate the rhythms of payment, debt, and circulation. ${ }^{7}$

\section{Distribution}

Grootplaas's white farmers live in a world of banked money, which routinely moves between countries and continents. Seeking out lucrative markets for their export-grade citrus crop, they respond to demand from different world regions through fruit agents. They travel to countries as far away as China to speak to potential new buyers, and Belgium to speak to middlemen. They routinely juggle different currencies, which exist for them primarily as numbers on screens.

Actually paying their workforce is a different matter. Here, money is material. For the white farmers along the border, month-end is a time of logistics and risk. The rhythm of money circulation shapes the lives of farmers at this time just as much as it does the lives of their workers. Pay has to be calculated, and cash brought. ${ }^{8}$ A total of approximately 1,000 permanently employed core workers on the border farms are joined during the harvest by a further 2,00o pickers and packers. Though farmers find ways to keep the pay of many seasonal workers under the South African monthly minimum (R989 in 2007), the scale of remuneration is huge. 
To complicate matters further, seasonal pickers, paid on piece rates, receive different and irregular amounts. Permanent employees and seasonal packshed workers are paid by the hour. But senior figures earn as much as R2,500, over two-and-a-half times the minimum wage. Packshed workers accumulate significant overtime for late nights on the conveyor belts, processing fruit picked during the day. All of this means that farmers require denominations covering the range of South African currency: from R10o banknotes to coins of $\mathrm{R} 1$ and lower.

Collecting the cash in cars and pick-up trucks from Musina comes with obvious hazards. Farmers speak of criminals' co-ordinated efforts to monitor their movements in Musina around the end of the month. Cash has been stolen from their vehicles. Robbery on the farm itself provokes far greater fear. Stories from other farms underline the risk. One Grootplaas labourer formerly worked on a nearby estate at which, as the workforce queued for pay, men arrived with AK-47 automatic weapons and made off with the money.

The actual distribution of wages is a highly ritualized event, marking its central place in the monthly cycle. Some workers, having washed after the morning's labour, recognize the occasion with clean, often new, clothes. The moment of pay is less dignified, however. As seasonal workers form into queues, a work supervisor beckons each to a table, grabs a thumb, presses it onto an inkpad, and 'signs' for pay. The implications of their treatment as uneducated are not lost on the mostly literate Zimbabwean migrants, some of whom, uprooted by crisis at home, have extensive formal schooling and middle-class self-understandings.

Directed to a window in the wall behind the table, each worker receives a white paper packet. Antiquated dot matrix type adorns the envelopes, specifying the worker and the amount paid. This ensures against miscounting, but it is virtually impossible for workers to ascertain that their pay matches a month of piece rates, or packshed overtime with its ill-defined distinction between 'work' and 'clearing up'. Among pickers, pay confirms broad differences between gangs - supervisors have been driving the work pace for months by means of taunting comparisons. But the collection of coins and banknotes each worker receives appears remote from any discernible units of labour. Of greater concern for each worker leaving the workshop with a paypacket is what to do with it, and how to keep it safe.

\section{To remit, or not to remit?}

Most workers come to the farms to earn money to send home to Zimbabwe. And each month, some take earnings in person - by taxi, or by bicycle for quick journeys across the border. One mid-harvest payday in 2007 , for example, thirty-three of fifty-three randomly selected seasonal workers at Grootplaas went home. A further two sent earnings with their wife or neighbour. Fewer permanent workers from Grootplaas travelled home in the same mid-harvest month in 2007 - only twenty of a sample of forty-nine - although a further three sent someone else with remittances.

Why do more not go? Making the journey home is no simple matter. During the period of fieldwork, undocumented seasonal workers faced deportation on the border road. For anyone, a short cut through the border fence means risking robbery and rape at the hands of magumaguma, gangs that operate along the Limpopo River. And, until the hyperinflatory Zimbabwean dollar was abandoned in 2009, black-market currency conversion in Beitbridge, the Zimbabwean border town, came with the danger of arrest. Furthermore, many underpaid seasonal workers are unable to accumulate what they 
imagine will meet their kin's expectations. Like Worby's (2010) Zimbabwean informants in Johannesburg, such workers often avoid contact with home, worried about disappointing family members.

Whether Grootplaas residents do remit, and how much, is partly a question of their pay rates and their plans: work on the border and then return home, or reach Johannesburg. But life in the compound also competes. Residents strive for a degree of stability. Permanent workers have established lives on the farms, and some even have farm families: wives and children whom they could not take home to Zimbabwe, but who constitute relationships that have permanence at Grootplaas. Domestic arrangements involve money. Men provide shelter and some of their earnings in return for cooking, housekeeping, and sexual access (see Bolt 2013). Meanwhile, members of church groups and football teams make cash contributions, for burials and competition fees, respectively, binding them into the fabric of farm life. Senior workers regularly convert their money into more enduring status by purchasing stylish evening and weekend attire: faux-leather jackets, cowboy hats, the latest button-down shirts, and football strips of top South African teams like the Orlando Pirates or Kaiser Chiefs. The most senior figures display their largesse by buying beer or, in one case, by securing funding to support the seasonal-worker football team he founded. ${ }^{9}$

Members of the seasonal workforce, with their short-term contracts, have fewer options. Their shared housing offers little scope for domestic relationships, and most earn far less than permanent workers. Nevertheless, albeit in a more fragmentary manner, some develop commitments to church groups or contribute to their footballteam kitty. Male seasonal workers are known for spending substantial portions of their earnings on women and beer, a way to convert money into everyday sociality. Seasonally employed women, meanwhile, may establish relationships with permanent workers during the harvest, but this means that they accumulate, rather than spend, cash. In any case, working in the packshed on an hourly rate, they are far better paid than their male counterparts in the orchards. They are also far more likely to be embedded in existing kin or sexual relationships at the farm, and their monetary practices reflect this. Some young women give a portion of their earnings to older kin, a contribution to remittance. Others simply make the most of a greater range of social connections through which to safeguard their savings, as I show later.

While farm life often depletes residents' savings, it also provides the social channels by which remittance is possible. As in many other migrant-labour settings, people rely on one another to convey money. But, for newcomers who arrive alone, from far afield, a brief stint on the border farms may leave little opportunity to make arrangements. During the period of fieldwork, many would simply stock up on basic supplies that were scarce in Zimbabwe, and take these home at the end of the season for use or resale (see Bolt 2012).

Accumulation, too, depends on close relationships. Permanent workers are involved in small rotating credit groups, which emerge and disappear depending on their members' reliability. As they accumulate, permanent workers rely on better personal security and the fact that they are more embedded on the farms than transient harvesttime workers. Those who remit often wait for a longer trip home for annual leave, sometimes co-ordinating remittance flows with kin elsewhere in South Africa.

All of this means that a considerable amount of money remains in the workforce. But, more importantly for this article, money itself plays a crucial role in Grootplaas 
residents' competing goals: establishing a reasonably congenial life on the farm versus remitting to kin or saving for transport to Johannesburg. Until it is spent - converted into another form of value - money offers a uniquely open-ended future, leaving decisions undetermined (see Graeber 1996). When newcomers arrive at Grootplaas, the relationships they establish have much the same attraction. They keep possibilities open. As long as different plans coexist, cash remains crucial, despite the difficulties associated with looking after it. And the relationships established because of and through cash, described in detail below, are important for much the same reason. They can root recruits in farm life for the moment, but they can also preserve the money that makes future plans thinkable.

I turn, therefore, to the money that is neither remitted nor consumed. This money, especially, is the stuff of sociality at Grootplaas. To understand the particular ways that money mediates relationships on the farm, we need first to turn to the particular risks presented by the border setting.

\section{Storing value: the problem with cash}

In standard definitions, a key feature of money is that it is a store of value. But storing money itself on the border is no simple matter. While farmers have difficulty bringing cash to Grootplaas, their workers have difficulty looking after it. Large-scale mobility means there are always strangers around the compounds. Meanwhile, the police presence is overwhelmingly focused on maintaining the integrity of the border, rather than protecting its resident workforces. Money commonly offers its owners dual possibilities: public display, or hidden potential (Graeber 1996). But on the Zimbabwean-South African border, the lack of everyday security encourages workers to keep their money out of sight as far as possible.

Unlike along the Limpopo riverbed, where magumaguma gangs operate, open robbery is virtually unknown in the compounds. This is doubtless because of the risk of immediate, violent reprisals. Vigilante justice is rare, but demonstrates to everyone in the area what could happen. On one occasion, two workers, who had fled after drunkenly assaulting another with a length of electrical cable, returned for their wages. Entering the compound, they stole clothes from one of the rooms, but were tracked down in the bush by a security guard and around thirty male workers, who took them to the football field, beat them, and then marched them to the white farmer. The farmer recommended a further beating, then handing the culprits to the local army garrison. Fearing serious injury to the young men, Marula,${ }^{10}$ the black foreman, interceded and took them directly to the soldiers. Identified criminals are labelled magumaguma (in other words, identified with the gangsters of the border), justifying levels of violence that would never be visited upon those considered residents. This, needless to say, is a powerful deterrent.

However, if a thief is not caught red-handed, the risks are far lower. The police are rarely present in this remote part of the border (when not rounding up deportees). The foreman, Marula, holds court at his house in the manner of a headman, and hears disputes about theft. But the process inevitably takes too long and begins to appear pointless. Victims, realizing that their money is irrecoverable, simply concede. At this point, it makes more sense to visit a ng'anga (diviner-healer). Ng'angas offer the possibility of detecting culprits, not to recover the money, but to wreak revenge, such as by causing insanity. I heard of no cases where this had happened in response to theft specifically, ${ }^{11}$ but the fact that detection and retaliation are possible discourages 
wrongdoing. One informant made a point of drawing my attention to a mentally ill man in the compound, who stands as a warning of what could happen to criminals.

Despite all of this, opportunistic theft is a constant risk; something I came to realize soon after arriving on the border. I began residence in the Grootplaas compound during the off-season, the period when only the permanent workforce and its dependants are resident at the farm. The tightly connected, embedded population I found appeared one in which possessions were secure. But my host, a senior worker, was keen to impress on me how misleading this impression was. He was fastidious about locking the door to his accommodation when out of sight of it, even when very close by. And indeed, within a few weeks, an established, respected pump operator known as Smooth had been burgled. He had left the door to his room open on Christmas Day while he visited friends around the compound. After a few beers, he returned to find that all of his savings and clothes had disappeared. Nicknamed for his sartorial elegance, Smooth's open room was doubtless a particularly lucky find. Of course, his possessions were never recovered. This tension, between apparent security and the risk of theft, is one that simultaneously produces constant concern and momentary carelessness. As one long-term resident put it, 'If you knew [theft] would happen on such and such a day, you would lock your door on that day, but as you do not [know], you might just leave it open'.

For the many businesspeople resident in the farm compounds, the risks are yet greater because they are known to keep money and goods in their rooms. During the period of fieldwork, one shop on a neighbouring farm was emptied of its stock and television. It was later said that the owner had left soon afterwards, unable to sustain business after such a loss. The dozen or so informal taxi drivers face similar risks. They stay with kin or partners on the farms, and ply the route to the border post and Musina with their pick-up trucks. At Grootplaas, they must park in a designated area on the edge of the compound. If they leave anything in their vehicles overnight, they are sure to find smashed windows in the morning. In this setting, cash is far from a neutral form of wealth. Its form has palpable consequences. It is easily concealed, entirely generic in appearance, and therefore problematically fungible. Once it has been stolen, it is virtually impossible to distinguish one's own money from someone else's.

The compound is an austere, barrack-like place, with its rows of brick blocks and metal doors. But at least permanent workers are allocated their own accommodation, and are able both to personalize it and to accumulate possessions and earnings, their rooms protected by padlocks.

Seasonal workers lack this basic security. Some women are relatives or sexual partners of permanent employees, and are able to reside with them. But the majority of the seasonal workforce lives a less rooted existence. When they arrive, they are allocated spaces on the concrete floors of overcrowded rooms. Living with strangers in cramped housing makes it hard to store earnings safely. Some are able to swap rooms, so that they reside with others from their home area. But this depends on the good fortune of finding swapping partners. And, of course, they must have friends from home in the first place - something much more common among those who hail from the south of Zimbabwe, near the border. To make matters worse, the doors can only be secured with a padlock. With so many residents, doors remain unsecured and, to avoid overcrowding, people turn to living outside - this in a distinct area of the compound where there are often strangers because of high labour turnover. The area, associated primarily with the transience of the seasonal workforce, is known for its shebeens and rowdy 
behaviour. Overcrowded accommodation with strangers, unlocked doors, and a busy free-for-all make the safe storage of any goods, but especially cash, very difficult.

The fact that many seasonal workers remain undocumented for long periods of time - sometimes the whole harvest, owing to administrative backlogs at the local Department of Home Affairs - further deepens their insecurity. During the mass deportations that characterized the period of the Zimbabwean crisis, it was not uncommon for new arrivals to avoid their rooms altogether for fear of detection by the police or army. ${ }^{12}$ Despite the fact that the harvest spanned the bitterly cold winter, many would sleep in hiding, in the bush some distance from the compound. Along with their living conditions, seasonal workers' fugitive existence and the possibility of sudden, immediate deportation mean that it makes little sense for them to store their earnings in their accommodation. Many keep cash in their pockets. But this is hardly a satisfactory solution, given the risk of extortion during deportation, or robbery afterwards while crossing back into South Africa. The alternative is to seek out protectors in the workforce.

\section{The hierarchy of the cash economy}

Cash presents particular problems for the harvest-time workforce. One common solution is to develop relationships with permanent workers, who safeguard each month's remuneration until it is needed. Away from the shebeens, permanent workers' housing areas are quieter and the people who frequent them well known. Most importantly, permanent workers are able to lock their doors. In a place of mobility and strangers, access to a secure room in which to keep cash and other possessions is of clear importance.

Becoming well acquainted with permanent residents is therefore to seasonal workers' advantage, and the forms of dependence that develop often have the safeguarding of wages at their heart. Although most seasonal workers are integrated in senior figures' social networks to only a limited extent, there are several ways to develop relationships with them. Some seasonal workers are fortunate: they hail from the same home areas as potential protectors. Others quickly learn to cultivate connections through work itself: the ability to banter can become a resource in finding a patron. But senior permanent workers are also key figures in the life of the compound. As previously noted, one manages his own football team. His players keep their cash either with him or with the team's coach, both of whom safeguard considerable amounts. Another work supervisor is the prophet who runs the branch of the African Apostolic Church. Marula, the foreman, acts as a chief-like figure within the farm's working population. He is known to take people under his wing, and even house them, if they present their problems to him. These forms of connection are often hard to distinguish in practice. One picking supervisor has a history of recruiting people from Gundu, his home area in Zimbabwe, to his picking team. When employment lists revealed that over 90 per cent of his pickers were from one place, he was told to stop. But such practices are common. Permanent workers are local notables on the farms, their authority general, and their connections to seasonal workers broad-based.

Looking after seasonal workers' money (and sometimes their supply of mealie (maize) meal or items they have purchased such as spades) cements permanent workers' positions in the farm's hierarchy. Doing so can establish one man as the senior figure amongst his relatives on the border farms. More generally, looking after cash 
without asking for anything in return enables permanent workers to gain influence and status by accumulating dependants. Others seek pecuniary gain: they act as banks, lending the money on at interest.

For seasonal recruits, entrusting senior figures with earnings comes with its risks. Sometimes, money lent on to third parties is not repaid. In such cases, permanent workers have been known simply to abrogate responsibilities to their depositors. They may even simply spend the money they are supposed to safeguard, and later claim that it was stolen. In general, however, permanent workers are not known for betraying trust, because their positions as central figures in the farm hierarchy are too important to them. In cases where money was actually stolen, or lost to fire, upstanding permanent workers have reportedly even repaid the amount in instalments, to diffuse any rumours of wrongdoing. But ultimately, in such an unequal situation, honesty and generosity are permanent workers' prerogatives. Seasonal workers may take their cases to Marula's court, but the elders who preside there are a tight-knit cadre of picking supervisors. Permanent workers largely make the rules. Nevertheless, they do so with a view to maintaining prestige in the farm setting, and so act as patrons to seasonal labourers rather than simply exploiters. Reflecting this, some are referred to, more or less jokingly, as madala (old man).

One senior figure entirely abrogates these responsibilities. His case throws workforce expectations into relief. Michael, the personnel manager, formerly an army clerk in Zimbabwe, sees his job at Grootplaas in a corporate managerial idiom in which work and leisure time are sharply separated, in terms of social roles and obligations to other employees. In the compound, after work, he is known to tell others to sort out their own problems: 'You've got your job, I've got mine'. Other Grootplaas residents are deeply critical of this attitude, viewing him as someone who does not fulfil his role properly. His rival at the top of the hierarchy, the foreman Marula, charges him with being unreasonable in his dealings with subordinates. Michael is vilified, albeit quietly because of his power to hire and fire. Even those senior figures who drink with him exhibit glee when misfortune befalls him, such as when police arrested him on the road after discovering his false South African passport. All of this underlines the fact that compound residents evaluate senior workers according to their willingness to aid subordinates, including with their wages.

For the better known of the seasonal workforce - the regular faces, and the kin and sexual partners of senior figures - there are other ways of safeguarding wages. Although pickers are considered too transient, many of the women who work in the packshed are sufficiently embedded to draw on relationships with people with bank accounts. One informal taxi driver, a South African, deposits the earnings of packshed workers in his own account, and returns them at the end of the harvest, or when requested. From one woman he took R1500 (well over a month's wage), and she gave him R200 'in thanks' at the end of the season. This, of course, implies a great deal of trust. Taxi drivers, however, claim that their reliability is key to their business: remaining on good terms with farm residents ensures their livelihoods. Residents' concerns about wages produce the relationships that keep their enterprises alive.

Giving money to taxi drivers, in fact, most approximates permanent workers' own responses to everyday insecurity. Whereas the majority of seasonal workers can only remove cash from their accommodation or their person, but leave it in the compound, their more settled counterparts seek ways to remove cash from the farm setting altogether. Some money is, of course, kept on site - hidden in mattresses or, in the case of 
the owner of one combined spaza (informal general store) and shebeen, in an empty lunchbox. But finding a way to get money out of the compound is a priority, through connections to a bank account, or just to somewhere off the farm. One spaza owner is a relative of the wife of a game-farm manager down the road. Her income is far safer on the game farm, away from the bustle and prying eyes of the compound.

Safer yet is opening one's own bank account, something recently made easier by a change in the visa regime. ${ }^{13}$ An increasing number of permanent workers now have accounts, and deposit money in their Musina branch after pay. In such cases, bank accounts are seen primarily as safe places for cash. Some workers hold ATM cards for accounts opened by friends, so that they, too, have a safe place off the farm for earnings. And one spaza owner used the address of a relative in town to meet a bank's requirements. Bank accounts invite responsibilities, as they represent security not just for the holder, but also for others seeking to safeguard their earnings. Once again, taxi drivers are central to these arrangements. When they drive to town, they go with stacks of ATM cards and their PIN numbers, and deposit or withdraw cash (for a small contribution of R20 'for a cold drink'). In effect, the drivers represent money's route out of the compound.

A final strategy open to permanent workers is through the white farmers, who offer to look after some of their wages each month. Intended by the farmers as a mechanism for saving, this also removes cash from the compound altogether. Like the strategies discussed above, it depends on personal connections. Members of the small, core workforce, known to their employers, are able to approach them to request that some of the month's pay is held back. Doing so also requires steady employment and residence, and withheld wages are not simply available on-demand - at least not if many workers request them at the same time, such as before holidays. By keeping wages back, farmers become part of the webs of relationships through which workers look after their earnings, and through which the social world of the farm is in part constituted. Meanwhile, when workers leave their earnings with farmers, they effectively underline their open-ended residence at the farm.

Both seasonal and permanent workers' experiences reveal that the form money takes matters. Cash has consequences. The particular challenges and affordances of a cash economy in a transient, migrant-labour setting are visible in workers' own strategies and social relations. Money becomes central to different kinds of relational expertise on the border. Seasonal labourers seek to cultivate relations with their work supervisors, who cultivate their own social positions by offering a safe haven for wages. The latter, in turn, entrust earnings to white employers, to friends and relatives off the farm, or to banks in town. In all cases, cash, lacking personalized features, is easy to steal and difficult to track down. And so the primary concern is moving money up the farm's hierarchy, in the process reinforcing this hierarchy of dependence. Despite the considerable lengths to which farmers go to bring cash onto their estates, the concern of many workers is how to take their money back off the farm. Alongside all of this, permanent and seasonal employees move between forms of value (see Ferguson 1992), selectively converting cash into status, camaraderie, and rooted domesticity within the compound.

As they entrust and convert, many Grootplaas residents strive simultaneously to build their social positions and save money - intertwined projects to consolidate two reserves of future potential. This money-focused social action requires understanding in relation to time. I have shown how entrusting money can be an expression of an 
enduring relationship. But it is also crucial to appreciate the spikes in spending that follow payday each month, and the consequent cycles of credit and debt.

\section{Money in time: rhythms of payment and debt}

The delayed payday of 2007 underlines the central importance of a monthly rhythm in the money supply. Most obviously, the effects of late pay show how finely people at Grootplaas calibrate their actions to the timing of monthly remuneration. A three-day delay saw workers and market traders run out of food, complaints about slavery that painted farmers as colonial relics, and two celebrated bands fail to draw an audience.

More generally, the border farms' economies are built around a monthly cycle between the abundance and scarcity of cash. The range of people whose plans were confounded highlights the diverse enterprises that take advantage of the workforce's earnings after pay. Businesspeople, both visiting and resident, sell goods to the Grootplaas workforce, which represents a large concentration of regular incomes. Moreover, the large-scale debt collection in evidence - resident traders with their brown-paper account books - points to the centrality of credit. With workers paid once each month, a complex web of debt relationships ties them to businesspeople in the labour compound.

After payday, resident traders wait around the workshop yard, locating their customers, checking their accounts, and attempting to apprehend debtors, especially those in the seasonal workforce who, unlike core employees, may disappear as soon as they are paid. But most chasing must be done later in the evening, in the compound. Stopping every debtor as he or she leaves the workshop is impossible, especially for businesspeople who also earn a wage at the farm, and must therefore queue like everyone else. Permanent workers, meanwhile, will not abscond, but may refuse to pay, relying on their influence in the compound for leverage. Despite these problems, credit brings business, and to advance it is to demonstrate membership of compound society. Business depends on the goodwill of workers, especially those at the top of the hierarchy who control residence in the compound. Traders' precariousness ensures extremely generous terms of credit.

In rare cases, traders become reluctant to advance further credit to established employees, but even here there is a great deal of flexibility. This flexibility illuminates how credit works at Grootplaas, and the differences between permanent and seasonal workers in demanding it. Smooth, the senior worker and victim of theft discussed earlier, is known for his unreliability: he sometimes disappears after pay, clothesshopping trips to Musina being among his financial priorities. On one occasion, a hasty goodbye was followed by a quiet border crossing. He re-emerged several days later, having attended a relative's wedding in Zimbabwe. He had used his wages to buy large quantities of beer, sustaining his reputation at home as a successful man. Around the same time, it became clear that he was claiming he had no money, while using cash at the shebeens. Businesspeople refused to advance him credit, possibly because he was also in debt to his rather more influential friends in the permanent workforce. Nevertheless, he soon received more lenient treatment. By indicating that he intended to pay off some of his debt - but by no means all - he was able once again to buy on credit. For established permanent workers, demonstrating willingness in principle to pay what one owes is enough. Outstanding credit is an affirmation of the relationship between businessperson and customer. By settling the account, this relationship's open indeterminacy is cut short. The ultimate settlement of debts lies at a distant, unspecified point 
in the future. Cash feeds the credit economy in an ad hoc, long-term manner. By contrast, while credit enables their subsistence, seasonal workers have to settle their debts on a tight, short-term, monthly rhythm, because of their potential transience and their lack of clout in the compound. The conditions of credit for different residents index their embeddedness on the farm. At the same time, these contrasting conditions shape their prospects as social and economic actors.

This debt economy both responds to and produces sharp fluctuations in cash. Workers spend cash quickly, rely on debt, pay what is necessary after payday (almost everything if seasonal; substantially less if permanent), and then ask for further credit. During the cash-scarce periods, settled compound residents supplement their purchases on credit with resources that do not require money: gardens around the edges of the compound; access to the Limpopo River for fish, brokered through border guards; morogo (green-leaf vegetables, generically spinach in English) that grows wild under the citrus trees, fed by the farm's irrigation system. And they keep chickens, which they cross-breed with wild guinea fowl to boost numbers. By these means, residents are guaranteed relish, to accompany the maize meal that they buy to prepare vhuswa (Venda: porridge).

But the cash scarcity that pertains for much of the month is not simply because the money runs out. The monthly rhythm is itself partly driven by strategies of cash storage and use, in which farm residents attempt to remove their earnings from the farm. In the case of many permanent employees, money is simply out of reach. Others convert their wages to other kinds of wealth immediately after pay. The compound traders themselves are part of this pattern of periodic cash flight, through the orders for stock that they place with informal taxi drivers. Much of the money that reaches them when debts are repaid goes straight to the wholesale shops along Musina's high street and, via payments to taxi drivers, to petrol stations.

\section{Conclusion: wages and monetary circulation}

Stepping back from all this, what kind of circulation pattern does this produce on the border? A tentative answer suggests how anthropologists might contribute ethnographically to (usually rather ungrounded) discussions of monetary circulation. One might have assumed that the flow would simply be from farmers' banks to workers to workers' families in Zimbabwe. Some earnings do cross the border, as I have noted, but one important circuit is between Musina and the farms. The circulation of money and goods is a peculiar one here. Both cash and the goods that cash buys are brought to the farms from Musina or further afield. A key use of money, for those who earn it, is exchange among acquaintances in the compound. Matters are more peculiar still. Farmers bring cash, which flies through the compound for a short time, before much of it returns to town, and farm residents increasingly turn to credit. A lot immediately goes to traders, who take it to Musina to buy stock, often the same weekend.

Despite this odd circulation pattern, wages are socially productive. Money enables people to make their own lives meaningful, while leaving them at the mercy of wider forces (Hart 2005: 167). But here the circulation of wages produces something between 'micro' and 'macro'. Monetary circuits, monthly rhythms, and webs of sociality constitute one another. They transcend particular relationships, and even particular farms. Yet money's temporal and spatial organization along the border is less transient, and far more predictable, than the world around it. 
What, then, do wages do? In migrant-labour settings like Grootplaas, money embeds people. I have focused on the consequences of money's form. As wages are taken into the compound, problems of storage and spending precipitate new (or renewed) social ties, hierarchies, and dependencies. Attempts to manage money, on the one hand, and to establish relationships, social position, and farm-based personhood, on the other, intertwine. As compound residents create and maintain possibilities for life on the farm and beyond, sometimes with goals only provisionally articulated, the sociality of the wage is central. Much of this happens in the realm of short-term action, where money is often viewed as an instrument of selfish acquisition (Bloch \& Parry 1989). But at Grootplaas, the short-term world of money is complex, variegated, broader-reaching than exchange, and interwoven with people's establishment as social persons. The long term, meanwhile, remains undetermined. For migrant workers, the wage becomes a focus of efforts to enrich the present, materially and socially, and make contingencies for an uncertain future.

\section{NOTES}

For comments on drafts of this article, the author thanks Neville Bolt, Tom Boylston, Jane Guyer, Jason Hickel, Michael Hoffman, the 'Money in Africa' group, and participants of the Staff Writing and 'CWAS Talks' seminars at DASA, University of Birmingham. Matthew Engelke and three anonymous reviewers at the JRAI offered invaluable suggestions. Research was funded by the ESRC (PTA-031-2005-00006) during a Ph.D. at the LSE, and the Leverhulme Trust while employed on the British Museum's 'Money in Africa' project (F/oo 052/D).

${ }^{1}$ Then around $£ 800$, well over ten times the monthly wage of most farm workers.

${ }^{2}$ Then around 70 .

${ }^{3}$ Polanyi's focus is nineteenth-century England. But he is keen to draw parallels with colonial settings, including South Africa (Polanyi 2001 [1944]: 164-5).

${ }^{4}$ This is not, of course, the only strand in the anthropology of money. I discuss different perspectives below.

${ }^{5}$ It is questionable how voluntary their submission is, under the circumstances.

${ }^{6}$ Piot (1991), in his examination of Bohannon's spheres of exchange, similarly shifts the focus from valuable objects' meanings to the social relationships in which objects circulate.

${ }^{7}$ A methodological note. I lived in the Grootplaas labour compound (November 2006 to April 2008), and worked the harvest as a picker. This revealed the dynamics of insecurity, hierarchy, and dependency. Nevertheless, where people face extreme personal insecurity, monetary practices elude direct observation, or even open discussion. I often rely here on informants' explanations.

${ }^{8}$ The farmers at Grootplaas have now begun paying permanent workers through bank accounts. Reportedly, Zimbabweans with farm employment, travel papers, visas, and work permits have long been eligible for bank accounts. Actually securing one appears to have become easier, however. Since Zimbabwe's economic improvement, migrants have been able to acquire passports. Some permanent farm workers meanwhile acquired four-year South African visas during the Zimbabwe Documentation Project (see note 12). Reportedly, refugee papers also offered a route to bank accounts.

${ }^{9}$ Converting earnings into socially meaningful wealth is not always straightforward. When permanent workers establish their positions through adaptations to housing (stoeps, walls, or furniture), they rely on long-standing relations with builders and senior figures, who offer access to cement and scrap metal.

${ }^{10}$ All names are pseudonyms.

${ }^{11}$ Although there were cases of invisible attack with different motivations.

${ }^{12}$ The South African Police Service (SAPS) ceased mass deportations on the border in 2009. In 2011, deportations resumed. The moratorium coincided with the Zimbabwe Documentation Project, during which around 276,000 Zimbabweans were regularized (see Integrated Regional Information Networks 2013; on changing border policing, see Rutherford 2011).

${ }^{13}$ New four-year visas were received by many permanent workers, but only by those who were present on a particular day in 2011, when the Department of Home Affairs registered workers.

\section{REFERENCES}

BLOCH, M. \& J. PARRY 1989. Introduction: money and the morality of exchange. In Money and the morality of exchange (eds) J. Parry \& M. Bloch, 1-32. Cambridge: University Press. 
Bohannan, P. 1959. The impact of money on an African subsistence economy. Journal of Economic History 19, 491-503.

BoLt, M. 2012. Waged entrepreneurs, policed informality: work, the regulation of space and the economy of the Zimbabwean-South African border. Africa 82, 111-30.

2013. Producing permanence: employment, domesticity and the flexible future on a South African border farm. Economy and Society 42, 197-225.

Burawoy, M. 1979. Manufacturing consent. Chicago: University Press.

Comaroff, J. \& J.L. Comaroff 1990. Goodly beasts, beastly goods: cattle and commodities in a South African context. American Ethnologist 17, 195-216.

Donham, D. 2011. Violence in a time of liberation: murder and ethnicity at a South African gold mine, 1994. Durham, N.C.: Duke University Press.

Du Toit, A. 1993. The micro-politics of paternalism: the discourses of management and resistance on South African fruit and wine farms. Journal of Southern African Studies 19, 314-36.

ELster, J. 1985. Making sense of Marx. Cambridge: University Press.

Ferguson, J. 1992. The cultural topography of wealth: commodity paths and the structure of property in rural Lesotho. American Anthropologist 94, 55-73.

2013. Declarations of dependence: labour, personhood, and welfare in southern Africa. Journal of the Royal Anthropological Institute (N.S.) 19, 223-42.

Gilbert, E. 2005. Common cents: situating money in time and space. Economy and Society 34, 357-88.

Gordon, R.J. 1977. Mines, masters and migrants: life in a Namibian compound. Johannesburg: Ravan Press.

Graeber, D. 1996. Beads and money: notes toward a theory of wealth and power. American Ethnologist 23, 4-24.

GuYer, J. 2004. Marginal gains: monetary transactions in Atlantic Africa. Chicago: University Press.

HART, K. 2005. Money: one anthropologist's view. In A handbook of economic anthropology (ed.) J.G. Carrier, 160-75. Cheltenham: Edward Elgar.

Integrated Regional Information Networks 2013. Deported from South Africa, Zimbabweans struggle at home (available on-line: http://www.irinnews.org/report/98174/deported-from-south-africazimbabweans-struggle-at-home, accessed 22 October 2013).

McNamara, J.K. 1985. Black worker conflicts on South African gold mines: 1973-1982. Ph.D. thesis, Witwatersrand University.

Maurer, B. 2005. Does money matter? Abstraction and substitution in alternative financial forms. In Materiality (ed.) D. Miller, 140-64. Durham, N.C.: Duke University Press.

2006. The anthropology of money. Annual Review of Anthropology 35, 15-36.

Mollona, M. 2009. General introduction. In Industrial work and life: an anthropological reader (eds) M. Mollona, G. de Neve \& J. Parry, xi-xxviii. Oxford: Berg.

Moodie, T.D. with V. Ndatshe 1994. Going for gold: men, mines, and migration. Berkeley: University of California Press.

Murray, C. 1981. Families divided: the impact of migrant labour in Lesotho. Cambridge: University Press.

Ріот, C. 1991. Of persons and things: some reflections on African spheres of exchange. Man (N.S.) 26, 405-24.

Polanyi, K. 2001 [1944]. The great transformation: the political and economic origins of our time. Boston: Beacon Press.

RUTHERFORD, B. 2001. Working on the margins: black workers, white farmers in postcolonial Zimbabwe. London: Zed Books.

2011. The politics of boundaries: the shifting terrain of belonging for Zimbabweans in a South African border zone. African Diaspora 4, 207-29.

Shipton, P. 2007. The nature of entrustment: intimacy, exchange, and the sacred in Africa. New Haven: Yale University Press.

TAUssig, M.T. 1977. The genesis of capitalism amongst a South American peasantry: devil's labour and the baptism of money. Comparative Studies in Society and History 19, 130-55.

Walsh, A. 2003. 'Hot money' and daring consumption in a northern Malagasy sapphire-mining town. American Ethnologist 30, 290-305.

Worby, E. 2010. Address unknown: the temporality of displacement and the ethics of disconnection among Zimbabwean migrants in Johannesburg. Journal of Southern African Studies 36, 417-31.

Zelizer, V. 1989. The social meaning of money: 'special monies'. American Journal of Sociology 95, $342-77$.

Journal of the Royal Anthropological Institute (N.S.) 20, 113-130

(C) 2014 The Authors Journal of the Royal Anthropological Institute published by John Wiley \& Sons Ltd on behalf of Royal Anthropological Institute 


\title{
La socialité du salaire : rythmes de l'argent, circulation de la richesse et problème de l'argent liquide à la frontière entre le Zimbabwe et l'Afrique du Sud
}

\begin{abstract}
Résumé
Si le travail rémunéré et l'argent ont déjà été largement étudiés en anthropologie, il n'en va pas de même de la paie elle-même, des billets de banque et pièces qui sont effectivement distribués aux travailleurs. Le présent article retrace la productivité sociale des paies des ouvriers agricoles à la frontière entre le Zimbabwe et l'Afrique du Sud. Dans ce contexte de travail migrant, la forme de l'argent est importante. Les objets monétaires étant matériellement les mêmes, les travailleurs ont des difficultés à les mettre à l'abri dans un environnement peu sûr ; ils ont alors recours les uns aux autres. En gérant leurs gains, les ouvriers tentent d'acquérir un statut de personnes sociales, tout en se ménageant des options pour l'avenir dans des circonstances incertaines. Les liens entre les salariés donnent formes aux flux de liquidités et aux rythmes et circuits de la paie, tout en étant modelés par ceux-ci. Si on la considère en termes de forme, la paie est quelque chose de très personnel : l'étoffe même de la socialité.
\end{abstract}

Maxim Bolt is Lecturer in Anthropology and African Studies in the Department of African Studies and Anthropology, University of Birmingham, and Research Associate at the Wits Institute of Social and Economic Research (WISER), University of the Witwatersrand. He is finalizing two monograph manuscripts: The Roots of Impermanence: settlement, transience, and farm labour on the Zimbabwean-South African border, and Money in Africa, a comparative collaboration with three historians.

Department of African Studies and Anthropology, Arts Building, University of Birmingham, Edgbaston, Birmingham B15 2TT, UK. m.bolt@bham.ac.uk 